\title{
Comparison of the Palaeomagnetic Parameters of Non-Marine Jurassic-Cretaceous Boundary Sediments in Dorset (SW England), Hebei and Liaoning (NE China) - A Preliminary Study
}

\author{
Petr Schnabl ${ }^{*}$, Gang Li², Šimon Kdýr ${ }^{1}$, Gunther Kletetschka1, Petr Skupien³ ${ }^{3}$ Andrea Svobodová1, \\ Karolína Hladíková ${ }^{1}$, Meizhen $\mathrm{Cao}^{2}$, William A. P. Wimbledon ${ }^{4}$ \\ ${ }^{1}$ Institute of Geology of the Czech Academy of Sciences, Prague, Czech Republic \\ ${ }^{2}$ State Key Laboratory of Palaeobiology and Stratigraphy, Center for Excellence in Life and Environment, Nanjing Institute \\ of Geology and Palaeontology, Chinese Academy of Sciences, Nanjing, China \\ ${ }^{3}$ Faculty of Mining and Geology, VSB Technical University of Ostrava, Ostrava-Poruba, Czech Republic \\ ${ }^{4}$ School of Earth Sciences, University of Bristol, Bristol, UK \\ Email: *schnabl@gli.cas.cz
}

How to cite this paper: Schnabl, P., Li, G., Kdýr, Š., Kletetschka, G., Skupien, P., Svobodová, A., Hladíková, K., Cao, M. and Wimbledon, W.A.P. (2019) Comparison of the Palaeomagnetic Parameters of Non-Marine Jurassic-Cretaceous Boundary Sediments in Dorset (SW England), Hebei and Liaoning (NE China)-A Preliminary Study. Open Journal of Geology, 9, 654-657. https://doi.org/10.4236/ojg.2019.910066

Received: August 16, 2019

Accepted: September 21, 2019

Published: September 24, 2019

Copyright $\odot 2019$ by author(s) and Scientific Research Publishing Inc. This work is licensed under the Creative Commons Attribution International License (CC BY 4.0).

http://creativecommons.org/licenses/by/4.0/

\begin{abstract}
The Purbeck beds in Dorset, the Tuchengzi Formation in western Liaoning Liaoning Province or the Houcheng Formation in northern Hebei Province are non-marine Jurassic/Cretaceous $(\mathrm{J} / \mathrm{K})$ boundary sequences. A Czech-China Inter-Governmental S\&T Cooperation Project has been carried out to search for the non-marine $\mathrm{J} / \mathrm{K}$ boundary in northern China and making international correlation with the Purbeck beds in southern England. The combination of palaeomagnetism and biostratigraphy in northern China and southern England localities proves that these distant places had similar climatic conditions and the same fauna during the Late Jurassic and Early Cretaceous. A preliminary joint research has shown a fruitful result in searching for the non-marine J/K boundary in northern China.
\end{abstract}

\section{Keywords}

Jurassic-Cretaceous Boundary, Dorset, Northern Hebe, Western Liaoning, Palaeomagnetism, Biostratigraphy

\section{Introduction}

A joint study of the Jurassic/Cretaceous $(\mathrm{J} / \mathrm{K})$ boundary sections in northern China [1] and Dorset, southwestern England [2] [3] began in the year 2017. In 
northern China the well-developed non-marine Upper Jurassic to Lower Cretaceous sequences are widely distributed, which straddle the $\mathrm{J} / \mathrm{K}$ boundary, and suitable for the study of the J/K boundary magnetostratigraphy [4] [5].

In recent years, more and more precise radiometric dating data indicate that the Tuchengzi Formation in western Liaoning and the contemporaneous Hocheng Formation in northern Hebei straddle the J/K boundary [6] [7]. Palaeomagnetic and magnetostratigraphic research clarifies and constrains interpretations of the $\mathrm{J} / \mathrm{K}$ boundary interval.

The studied Dorset sites are on the Isle of Portland and at Swanage. The first, the older, is Jurassic in age. It consists of six successive sequences. Layered marine cherty limestones are below and homogeneous Portland "freestone" carbonates being above, with the non-marine Purbeck beds overlying. The other section is the major cliff profile at Swanage, entirely in continental Purbeck sediments, of Tithonian to Berriasian age.

\section{Methods}

Palaeomagnetic methods used differ between the carbonate rocks and clastics. Thermal demagnetisation dominated for the Portland Stone limestone and the sediments in the upper part of the Swanage section. Alternate field demagnetization was performed on the more clastic sediments in the lower part of the Swanage Purbeck section and on all the Chinese samples. The main carriers of magnetization were investigated using analysis of the isothermal remanent magnetization curve following Kruiver et al. [8].

\section{Results}

We show that in Hebei and Liaoning the sedimentation rate was so rapid that individual studied profiles contain only one magnetozone, which is an advantage for magnetostratigraphy when it is used as an aid for the $\mathrm{J} / \mathrm{K}$ boundary determination. Specifically, we have found that both measured profiles of the Houcheng Formation in northern Hebei have a normal polarity, whereas the measured profile of the Tuchengzi Formation displays a reverse polarity. The individual profiles are to be stratigraphically linked.

The preliminary results on the Portland sediments prove only one normal polarity zone with one subzone. The first result from pilot sampling in the Purbeck beds at Swanage shows at least three normal and two reverse polarity zones.

Additionally, we have identified fossils of the clam shrimps (Diplostraca) [9] [10] and ostracods (Ostracoda) and combined them with magnetostratigraphy. This allowed correlations of sites in northern China with southern England.

\section{Discussion}

More magnetozones might be still recognized in both areas. The sampling in northern China has to continue above and below the sampled profiles, and the section at Swanage has to be sampled more densely. Measurement of previously 
sampled specimens still continues. Bed-by-bed correlation of the results between the studied part of the Swanage section and the results of Ogg et al. [11] is a priority.

\section{Acknowledgements}

This work was financially supported by Mobility project of Czech Ministry of Education, Youth and Sports and Ministry of Science and Technology of the People's Republic of China (8H17050), institutional support of Inst. Geol. Czech Acad. Sci. (RVO67985831), the Strategic Priority Research Program of Chinese Academy of Sciences (XDB26000000), China-Czech $42^{\text {th }}$ Inter-Governmental S\&T Cooperation Project (42-3), the National Natural Science Foundation of China $(41572006,41688103,41972007)$ and UNESCO/IUGS/IGCP 679 project.

\section{Conflicts of Interest}

The authors declare no conflicts of interest regarding the publication of this paper.

\section{References}

[1] Wang, W.L., Zhang, H., Zhang, L.J., Zheng, S.L., Yang, F.L., Li, Z.T., Zheng, Y.J. and Ding, Q.H. (2004) Standard Sections of Tuchengzi Stage and Yixian Stage and Their Stratigraphy, Palaeontology and Tectonic-Volcanic Actions. Geological Publishing House, Beijing, 514 p. (In Chinese)

[2] Wimbledon, W.A.P., Casellato, C.E., Reháková, D., Bulot, L.G., Erba, E., Gardin, S., Verreussel, R., Munsterman, E.K. and Hunt, C.O. (2011) Fixing a Basal Berriasian and Jurassic/Cretaceous (J/k) Boundary-Is There Perhaps Some Light at the End of the Tunnel. Rivista Italiana di Paleontologia e Stratigrafia, 117, 295-307.

[3] Horne, D.J. (2002) Ostracod Biostratigraphy and Palaeoecology of the Purbeck Limestone Group in Southern England. Special Papers in Palaeontology, 68, 53-70.

[4] Li, G. and Matsuoka, A. (2015) Searching for a Non-Marine Jurassic/Cretaceous Boundary in Northeastern China. Journal of Geological Society of Japan, 121, 109-122. https://doi.org/10.5575/geosoc.2015.0001

[5] Xi, D.P., Wan, X.Q., Li, G.B. and Li, G. (2019) Cretaceous Integrative Stratigraphy and Timescale of China. Science China Earth Sciences, 62, 256-286. https://doi.org/10.1007/s11430-017-9262-y

[6] Xu, H., Liu, Y.Q., Kuang, H.W., Liu, Y.X. and Peng, N. (2017) Jurassic-Cretaceous Terrestrial Transition Red Beds in Northern North China and Their Implication on Regional Paleogeography, Paleoecology, and Tectonic Evolution. Palaeoworld, 26, 403-422. https://doi.org/10.1016/j.palwor.2016.05.007

[7] Xu, H., Liu, Y.Q., Kuang, H.W., Jiang, X.J. and Peng, N. (2012) U-Pb SHRIMP Age for the Tuchengzi Formation, Northern China, and Its Implications for Biotic Evolution during the Jurassic-Cretaceous Transition. Palaeoworld, 21, 222-234. https://doi.org/10.1016/j.palwor.2012.10.003

[8] Kruiver, P.P., Dekkers, M.J. and Heslop, D. (2001) Quantification of Magnetic Coercivity Components by the Analysis of Acquisition Curves of Isothermal Remanent Magnetisation. Earth and Planetary Science Letters, 189, 269-276. https://doi.org/10.1016/S0012-821X(01)00367-3 
[9] Li, G. and Matsuoka, A. (2012) Jurassic Clam Shrimp ("Conchostracan") Faunas in China. Science Report of Niigata University (Geology), 27, 73-88.

[10] Wang, S.E. and Li, G. (2008) New Fossil Clam Shrimps from the Tuchengzi Formation of Northern Hebei and Western Liaoning. Acta Palaeontologica Sinica, 47, 319-325.

[11] Ogg, J.G., Hasenyager, R.W. and Wimbledon, W.A. (1994) Jurassic-Cretaceous Boundary: Portland-Purbeck Magnetostratigraphy and Possible Correlation to the Tethyan Faunal Realm. Geobios, 27, 519-527.

https://doi.org/10.1016/S0016-6995(94)80217-3 